\title{
More money available
}

\section{Sydney}

A SURPRISE boost for Australian science and technology was delivered by the government last week in a $\mathrm{A} \$ 1,000$ million increase in funding, tax cuts and scholarships. Under the banner "science creates wealth", the government hopes that the package, to be spent over the next six years, will encourage investment in research and development by industry and entice those entering science to make it a career.

Australia ranks fifteenth in the world in science spending by the private sector. To improve this rating, the government has extended its 150 per cent tax deduction on research undertaken by industry until June 1993. After that, a 125 per cent deduction will operate for a further two years, costing the government an expected A $\$ 640$ million.

Much of the new budget emphasizes increasing public awareness of science. Professor Ralph Slatyer, dean of the Research School of Biological Sciences at the Australian National University in Canberra, will take up the newly created position of Chief Scientist, advising the

\section{HIGHER EDUCATION}

\section{Bonn courts young} and females

\section{Hamburg}

WEST Germany is facing an education crisis unless young university faculty members are persuaded to keep their posts until an expected wave of retirements in the late 1990s. To head off the problem, West German Education Minister Jürgen Möllemann (Free Democrat) has announced a plan to invest DM800 million annually in salaries and research support for young researchers. So far, two Länder have voiced support for the plan, and Chancellor Helmut Kohl (Christian Democrat) has agreed in private that "something must be done", said a spokesman for the Education Ministry. Möllemann also plans to make funds available specifically for women researchers.

According to current plans, 60 per cent of the new money would come from the federal government and $\mathbf{4 0}$ per cent from the Länder. Achieving consensus on the plan could take six months or more and the amount of money could be reduced dramatically if federal and Länder finance ministers tighten the pursestrings.

But education has been a popular cause in West Germany lately. A programme to provide DM2,100 million in additional support for university teaching in overcrowded fields like business studies and information sciences came into effect earlier this year.

Steven Dickman
Prime Minister, Bob Hawke, and the Minister for Science, Barry Jones. Jones has increased his own status by becoming the Minister Assisting the Prime Minister on Science and Technology. Jones will also become the deputy chairperson on the new Prime Minister's Science Council, which will include representatives of the ministries associated with science and technology as well as members of the science and business communities

To raise international awareness of Australian science, the government has created the Australia Prize, worth A $\$ 250,000$ tax-free annually, to go to an international scientist or group of scientists for "excellence in promoting the welfare of peoples of the world". Other prizes include two MacFarlane Burnet Fellowships, each worth $\mathrm{A} \$ 230,000$, for

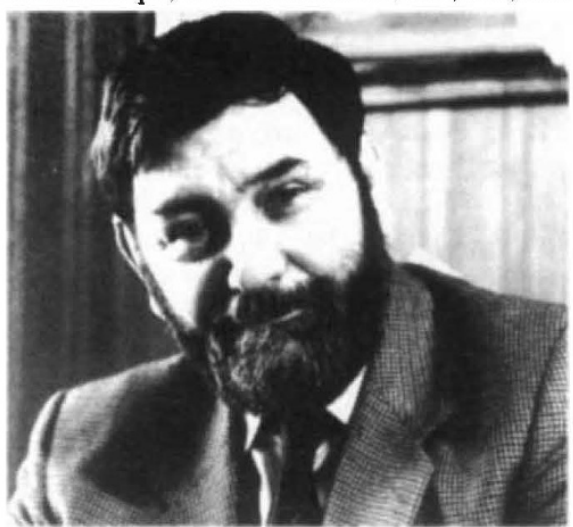

Barry Jones - up the ladder again.

medical scientists working overseas who wish to return to Australia.

Higher education was a big winner in the budget, receiving $\mathrm{A} \$ 977.9$ million over the next five years for research and postgraduate awards. From 1990, all Commonwealth postgraduate research awards will provide between A $\$ 12,734$ and $A \$ 16,433$ tax free, double what students received in 1986.

The Commonwealth Scientific and Industrial Research Organisation (CSIRO) remains the loser in the budget. In a week in which 500 staff were told they would lose their jobs or be transferred to other departments, the organization received only A $\$ 14$ million extra for 1989 90 , rising to $\mathrm{A} \$ 19$ million for each of the next four years.

But CSIRO needs A $\$ 250$ million merely to cover the budget cuts over the past five years. The budget loss for this coming year alone is $\mathrm{A} \$ 40$ million because of government cuts, a shortfall in private sector funding and a $\mathrm{A} \$ 14.2$ million accounting miscalculation. As Jones put it, "the incentive is clear for CSIRO to boost its revenue and research capacity by actively seeking a major industry $R \& D$ expenditure".

Tania Ewing

\section{Efforts abandoned in Japan}

\section{Tokyo}

News of cold fusion has caused wild excitement in Japanese laboratories, but so far all attempts to replicate the work have failed. Some researchers have already abandoned their efforts and, whatever might be said in US congressional hearings, there are no government plans to support a national research project.

Within days of the announcement by Utah research groups that they had achieved fusion in a flask, a broad-based effort to replicate the experiments began in dozens of laboratories around the country. Japanese scientists took to the research with the same unbridled enthusiasm they showed following the discovery of hightemperature superconductors two years ago. But this time all there is to show for their efforts is one false alarm.

On 1 April, Japanese newspapers reported that Noboru Oyama of Tokyo University of Agriculture and Technology had observed large amounts of heat and gamma rays when an electric current was passed between palladium and platinum electrodes in heavy water.

But Oyama says the press reported only the "positive" aspects of his results. Subsequent experiments in collaboration with researchers at the Japan Atomic Energy Research Institute have failed to detect emission of neutrons, tritium or helium-4. And calorimetry experiments will not be completed for several months, Oyama says.

Other groups with expertise in nuclear fusion and neutron detection report similar negative results. And a group at Hokkaido University headed by Hiroshi Ohashi announced a few weeks ago that it was abandoning its experiments because of failure to detect any products of nuclear fusion.

Nevertheless, interest in government and industry remains high because Japan, which depends on imports for most of its energy, would stand to gain enormously if cold fusion turned out to be a practical source of energy. And several symposia on cold fusion will be held over the coming weeks.

But, in contrast to the case of hightemperature superconductors, no government ministry or agency has established or plans to establish a 'study group' (kenkyukai) of industrialists and academics to promote national research on cold fusion.

Cold fusion still needs to be proved says Shigeharu Kato, deputy director of the Technology Development Division of the Science and Technology Agency's Atomic Energy Bureau, an organization that oversees Japan's research development of nuclear fusion.

David Swinbanks 